\title{
Influence of Surface Refinement on Microstructure of Al-Si Cast Alloys Processed by Wel- ding Method
}

Tomasz Lipiński

University of Warmia and Mazury in Olsztyn, The Faculty of Technical Sciences Department of Material and Machine Technology, St: Oczapowskiego 11, 10-957 Olsztyn, Poland. E-mail: tomekl@uwm.edu.pl

In most cases, construction materials are selected so as to attain the optimal technological properties at the lowest possible weight and cost. Studies on the improvement of the properties of casting alloys have been continuously conducted over the recent years. Both the microstructure and properties of alloys may be altered via modification with chemical components, optimization of the crystallization process, heat treatment or a combination of these methods. While searching for alternative methods of improving the engineering surface properties of hypo- and hypereutectic Al-Si alloy, an attempt was made to modify its microstructure with the use one of a heat sources. This paper presents the results of an experiment investigating the microstructure and the hardness of the $\mathrm{Al}-9 \% \mathrm{SiMg}$ and $\mathrm{Al}$ $20 \%$ SiMg alloys processed by TIG welding method.

Keywords: silumin, microstructure, hardness, modification, welding method

\section{References}

[1] MICHNA, S., LUKAC, I., OCENASEK, V., KORENY, R., DRAPALA, J., SCHNEIDER, H., MISKUFOVA, A. (2005). Encyclopaedia of aluminium, Adin s.r.o. Presov (in Czech).

[2] MONDELFO, L.F. (1978). Aluminium alloys: Structure and Properties, London, Butterworth.

[3] NÁPRSTKOVÁ, N., KUŚMIERCZAK, S., CAIS, J. (2013). Modification of AlSi7Mg0.3 alloy by strontium. In: Manufacturing Technology Vol. 13, No. 3, pp. 373-380.

[4] BOLIBRUCHOVÁ, D., RICHTÁRECH, L. (2013). Study of the gas content in aluminum alloys. In Manufacturing Technology, Vol. 13, No. 3, pp. 14-20.

[5] MICHALSKI, M., ROMANKIEWICZ, F. (2014). Research on the refinement mechanism of primary silicon particles on the basis of AlSi21CuNi alloy. In: Archives of Mechanical Technology and Automation Vol. 34, No. 2, pp. 33-40.

[6] WOŁCZYŃSKI, W., GUZIK, E., WAJDA, W., JĘDRZEJCZYK, D., KANIA, B., KOSTRZEWA, M. (2012). CET in Solidifying Roll - Thermal Gradient Field Analysis. In: Archives of Metallurgy and Materials No. 57, pp. 105-117.

[7] CUPRYŚ, R., MAJOR, B., WOŁCZYŃSKI, W. (2000). Transition of Flake into Fibre Structure in Eutectic AlSi. In: Materials Science Forum Vol. 329-330, pp. 161-166.

[8] ROMANKIEWICZ, F., ROMANKIEWICZ, R., REIFINFLUENCE, W. (2010). Of grain refinement on the structure of silumin AlSi7. In: International Journal of Applied Mechanics and Engineering Vol. 15, No 2, pp. 451-455.

[9] LIPIŃSKI, T., BRAMOWICZ, M., SZABRACKI, P. (2013). The Microstructure and Mechanical Properties of Al-7\%SiMg Alloy Treated with an Exothermic Modifier Containing Na and B. In: Solid State Phenomena Vol. 203-204, pp. 250-253. TTP Switzerland.

[10]T. LIPIŃSKI, The Effect of Na and B Exothermic Mixtures on the Hardness and Abrasive Wear of the AlSi7Mg Alloy. Archives of Foundry Engineering, vol.10, Issue 4, 2010, pp. 109-114

[11] ORŁOWICZ, A.W., BOLIBRUCHOVA, D., RICHTARECH L. (2014). Possibilities of eliminating the higher amount of iron in secondary AlSi7Mg0,3 Alloy by chrome. In: Communications vol. 16, No. 3A, pp. $119-123$.

[12]WASILEWSKI, P. (1993), Struktura i właściwości mechaniczne siluminu AK9 (AlSi9Mg). VI Konferencja Metale Nieżelazne w Przemyśle Okrętowym Szczecin-Świnoujście, pp.156-170

[13]BYDAŁEK, A.W. (1994). Surface effects of nitrogen in the slag refining of copper. In: Surface phenomena in foundry. Poznań - Kołobrzeg (in Polish).

[14]LIPIŃSKI, T. (2011). Use Properties of the AlSi9Mg Alloy with Exothermical Modifier. In: Manufacturing Technology Vol.11, No. 11, pp. 44-49. 
[15]LIPIŃSKI, T. (2008). Modification of the Al-Si Alloys with the use of a Homogenous Modifiers. In: Archives of Metallurgy and Materials, Vol. 53, Issue 1, pp. 193-197.

[16]NOVÁ, I., MACHUTA, J. (2013). Squeeze casting results of aluminium alloys. In: Manufacturing Technology, Vol. 13, No. 1, pp. 73-79.

[17]RADEK, N., MEŠKO, J., ZRAK A. (2014). Technology of Laser Forming. In: Manufacturing Technology Vol. 14, No. 3, pp. 428-431.

[18]WOŁCZYŃSKI, W., CUPRYŚ, R. (1999). The analysis of the influence of the Gibbs free energy onto the lamellarod transition in Al-Si alloy. In: Archives of Metallurgy vol. 44, No. 3, pp. 338-353.

[19]WRONSKA, A., DUDEK, A. (2014). Characteristics of surface layer of sintered stainless steels after remelting using GTAW method. In: Archives of Civil and Mechanical Engineering Vol. 14, No. 3, pp. 425-432.

[20]INGALDI, M., BORKOWSKI, S. (2014). Recycling Process of the Aluminium Cans as an Element of the Sustainable Development Concept. In: Manufacturing Technology Vol. 14, No. 2, pp. 172-178.

[21]Wrobel, A., Kucharska, B. (2009). Modification of Silicon Crystals in The Al-Si Coating by Means of Heat Treatment. In: Archives of Metallurgy and Materials Vol. 55, No. 1, pp. 205-210.

[22]BONDEREK, RZADKOSZ, (1999). Problems processing liquid aluminum alloys. In: Solidification of Metals and Alloys, Vol. 1, No. 41, pp. 153-159 (in Polish). 